\title{
Fotografia e Jornalismo: mais de um século de casamento feliz
}

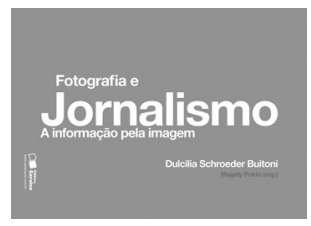

\section{Monica Martinez*}

PRADO, Magaly (org.); BUITONI, Dulcilia Schroeder. Fotografia e jornalismo. Coleção Introdução ao Jornalismo - v. 6. São Paulo: Saraiva, 2011. 208p.

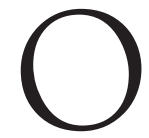
volume 6 da coleção Introdução ao Jornalismo, lançado no segundo semestre de 2011 pela Editora Saraiva, é um achado por vários motivos. A começar pelo título oportuno: Fotografia e Jornalismo - A informação pela imagem. Note que a obra não se limita ao estudo de fotojornalismo. Antes, o título já denota a concepção ampla, que só alguém que viu nascer a Escola de Comunicações e Artes da Universidade de São Paulo, como aluna da primeira turma de jornalismo da ECA-USP, poderia ter.

História, portanto, é algo caro à autora, Dulcília Schroeder Buitoni. Aqui e ali na obra - sem a linearidade que a faria enfadonha -, há pinceladas do contexto do nascimento da fotografia, como na página 9:

A nobreza começa a ser suplantada por uma nova classe social: a burguesia do negócio e do dinheiro. É uma classe que quer ser reconhecida; não tendo passado ilustre como os nobres, quer deixar uma imagem para a posteridade. Por isso, o retrato fotográfico encontrou um clima tão favorável para se desenvolver: todos queriam documentar a própria família. Quando os preços se

\footnotetext{
* Doutora em Ciências da Comunicação, é docente do Programa de Mestrado em Comunicação e Cultura da Uniso, Sorocaba-SP, Brasil.
}

Intercom - RBCC 
tornaram mais acessíveis, as classes populares também aderiram rapidamente ao retrato fotográfico.

Em outros momentos, a autora humaniza a narrativa, lembrando, claro, de nosso segundo e último imperador, D.Pedro II, um amante da ciência e tecnologia, ou, mais recentemente, nos anos 1980, quando também houve um redescobridor do nosso pai da fotografia: o professor Boris Kossoy, da ECA-USP.

Assim como o título faz uma ponte entre duas áreas, a autora viveu isso em sua própria vida profissional. Jornalista, ela era repórter da redação da revista Capricho, da Editora Abril - na época em que a revista era um marco na imprensa juvenil - quando participou, em 1972, da seleção para professora na ECA (cinco anos mais tarde se tornaria diretora daquela publicação). Tem, portanto, o jornalismo nas veias, mas a vocação para a docência falou mais alto. O que, aliás, é uma benção para os jovens professores de fotografia. Afinal, Buitoni compartilha com generosidade o conhecimento adquirido ao longo de sua trajetória de mestra.

Nos capítulos 2 e 3, a autora faz um mapa dos principais pensadores da fotografia: estão lá Phillip Dubois, André Bazin, Umberto Eco, Christian Mertz, Roland Barthes, Rudolf Arnheim, Pierre Bourdieu e Vilém Flusser, entre outros, sem esquecer dos brasileiros, como Arlindo Machado, Thomas Farkas, Fernando de Tacca, Helouise Lima Costa, Ronaldo Entler, Rubens Fernandes Junior, Luiz Eduardo Achutti e Maurício Lissovsky, além do próprio Boris Kossoy.

Diferentemente de alguns estudiosos, que se debruçam somente nas obras que os precederam, Buitoni olha para frente, totalmente antenada com as novas tendências. Hoje, aliás, ela é docente e pesquisadora do programa de pós-graduação em Comunicação da Faculdade Cásper Líbero, de São Paulo. Estão na obra os saberes que ela acumulou ao longo dos anos, por meio do diálogo com estudiosos como o espanhol Josep M. Català, da Universidad Autónoma de Barcelona, que se dedica ao estudo da complexidade da imagem, e o alemão WinfriedNöth, professor de Linguística e Semiótica da Universidade de Kassel.

A docente aponta, por exemplo, uma questão paradoxal dos estudos de visualidade contemporâneos, o que outro pesquisador 
brasileiro, Norval Baitello Jr., chama de iconofagia: o fato de estarmos sendo devorados pelo excesso de imagens ocas, esvaziadas de conteúdo simbólico.

Está certo que os aparatos tecnológicos também estão evoluindo. Hoje uma câmera digital das mais simples tem capacidade de 14 megapixels e zoom ótico de 10 vezes. Limites que serão considerados obsoletos muito em breve. Contudo, algo que não envelhece é a preocupação da autora para que as imagens não se tornem rasas como a dos catálogos, nem que sejam consumidas sem consciência da intenção com a qual elas foram feitas: "Não existe imagem inocente. É preciso ter repertório, é preciso observar e tentar imaginar todos os passos da produção de uma foto (p.7)”.

A partir daí, a obra mergulha numa análise erudita escrita em linguagem simples e acessível da relação entre o jornalismo e a fotografia. Contar mais seria tirar o prazer de o leitor mergulhar na obra. Mas os títulos dos capítulos seguintes já dão bem uma dimensão do que o leitor encontrará pela frente: "Fotografia e jornalismo: histórias"; "Usos jornalísticos da fotografia: informação, ilustração, expressão"; "Fotojornalismo: acontecimento, cena, paisagem, retrato"; "Mídia impressa brasileira: jornais, revistas e fotógrafos"; "Pedagogia do fotojornalismo"; "Agências e bancos de imagem: a questão autoral"; "Relação texto/imagem, imagem complexa, imagem estática, imagem em movimento"; "imagem jornalística televisiva: documentário videográfico e cinematográfico"; e "Imagem jornalística na Internet: novas visualidades fotográficas aplicadas ao jornalismo". Cada um deles traz um quadro chamado Caminhos que, como o próprio nome diz, sugere trilhas para refletir e se aprofundar no assunto.

A obra faz parte de uma coleção organizada pela docente Magaly Prado. 
